\title{
Amyloidosis of Seminal Vesicles; Incidence and Pathologic Characteristics
}

\author{
Seminal Vezikül Amiloidozu; İnsidans ve Patolojik Özellikleri
}

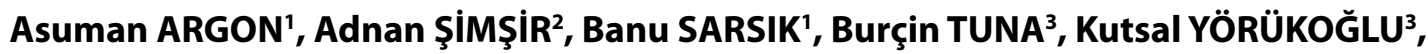 \\ Gülen Gül NifLioĞLU', Sait ŞEN' \\ Departments of ${ }^{1}$ Pathology and ${ }^{2}$ Urology, Ege University, Faculty of Medicine, IZMIR, TURKEY, \\ ${ }^{3}$ Department of Pathology, Dokuz Eylül University, Faculty of Medicine, IZMIR, TURKEY
}

\begin{abstract}
Objective: Amyloidosis is a rare disease with various etiologies with extracellular amyloid protein depositions. At present, at least 26 distinctive amyloid forms have been detected with different clinical importance and treatment. They have characteristic staning fetaures with Congo red. Amyloid may be detected in $2-10 \%$ of prostates that have been removed because of hyperplasia or carcinoma. Amyloidosis of seminal vesicles is accepted as senil amyloidosis and it is not accompanied by systemic amyloidosis or clinical symptoms. This condition is the most common form of localized amyloidosis. In this study we aimed to investigate incidence and histologic characteristics of amyloidosis of seminal vesicles in radical prostatectomy materials of the patients whose prostate carcinomas were treated surgically.
\end{abstract}

Material and Method: Amyloid depositions in seminal vesicles of 207 radical prostatectomy materials that prostates had been removed due to localized prostate carcinoma. Amyloid depositions were confirmed with Congo red staining and polarization microscope.

Results: Amyloidosis of seminal vesicles was detected in 10 (4.8\%) of cases. Mean age of the patients is 66.2 years. Amyloid depositions tend to be nodular and bilateral in subepithelial region of affected seminal vesicles. Amyloid depositions were not detected in blood vessels in seminal vesicles or prostate parenchyma.

Conclusion: Localized amyloidosis of seminal vesicles is not an unusual finding. amyloidosis of seminal vesicles incidence in Turkish patients included in this study and histopathologic characteristics of these patients are not different from the other studies. Systemic AA amyloidosis is the most common form of amyloidosis in our country. To be aware of amyloidosis of seminal vesicles is of importance in discrimination from the other forms of amyloidosis.

Key Words: Amyloidosis, Amyloid, Seminal vesicle
ÖZ

Amaç: Amiloidozlar farklı amiloid proteinlerin hücre dışında biriktiği, değişik etiyolojileri olan nadir hastalıklardır. Günümüzde dağılım, klinik önem ve tedavisi değişik olan en az 26 farklı amiloid formu tespit edilmiştir. Kongo kırmızısı ile karakteristik boyanma özellikleri taşırlar. Hiperplazi veya karsinom nedeniyle çıkarılan prostatların \% 2-10’unda amiloid saptanabilir. Seminal vezikül amiloidozu senil amiloidoz olarak kabul edilir ve sistemik amiloidozlar veya klinik semptomları birlikte değildir. Bu durum lokalize amiloidozların en yaygın formudur. Bu çalışmada, cerrahi olarak prostat karsinomu tedavi edilen hastaların radikal prostatektomi materyallerinde, seminal vezikül amiloidozu insidansı ve histolojik özelliklerinin araştırılması amaçlanmıştır.

Gereç ve Yöntem: Klinik olarak lokalize prostat karsinomu nedeniyle prostatları çıkarılan 207 radikal prostatektomi materyalinin vezikülo seminalislerinde amiloid birikimleri değerlendirilmiştir. Amiloid birikimleri Kongo kırmızısı boyama ve polarizasyon mikroskobu ile doğrulanmıştır.

Bulgular: Olguların 10'unda (\% 4,8) seminal vezikül amiloidozu saptanmıştır. Hastaların ortalama yaşı 66,2'dir. Amiloid birikimleri, etkilenen seminal veziküllerin epitel altı bölgesinde nodüler ve iki taraflı olma eğilimindedir. Vezikülo seminalislerdeki kan damarları veya prostat parankiminde amiloid birikimleri saptanmamıştır.

Sonuç: Lokalize seminal vezikül amiloidozu alışılmadık bir bulgu değildir. Bu çalışmaya dahil edilen Türk hastalardaki seminal vezikül amiloidozu insidansı ve bu hastaların histopatolojik özellikleri diğer çalışmalardan farklı değildir. Ülkemizde sistemik AA amyloidosis, amiloidozların en yaygın formudur. Seminal vezikül amiloidozu’nın farkında olmak, amiloidozların diğer formlarından ayırımında önemlidir.

Anahtar Sözcükler: Amiloidoz, Amiloid, Seminal veziküller 


\section{INTRODUCTION}

Amyloidoses are disorders characterized by local or systemic extracellular accumulation of proteinaceaous material with various chemical features due to various etiologies. Localized amyloidoses are derived from proteins synthesized from the cells at the region of accumulation while systemic amyloidoses appear as a result of the accumulation of normal or mutant proteins found in the plasma (1). Localized amyloidosis of the lower urinary system (bladder, ureter, prostate) is rare and more than half of the published cases have been localized to the bladder (2-4). Seminal vesicle amyloidosis (VSA) is an unusual localized finding and has been reported at a rate of 9-16\% in various autopsy series $(5,6)$. However, the incidence of VSA in surgical prostatectomy materials is said to be lower (7).

Detecting seminal vesicle metastasis during radical prostatectomies performed for prostate adenocarcinomas is quite important for staging. VSA is generally found during evaluation of the samples. Many authors feel that VSA found in radical prostatectomy material is an incidental finding (810). Pitkanen et al. have reported a VSA incidence of $21 \%$ in men aged over 75 and have stated that this incidence is due to the aging process and not related to systemic amyloidosis or clinical symptoms (6). However VSA can also lead to clinical findings such as hematospermia (11-13). Thickening due to accumulation in the seminal vesicles can also be interpreted as tumor invasion on magnetic resonance (MR) imaging and lead to incorrect staging of the prostate tumor $(14,15)$. The relationship with prostate cancer and effect on tumor invasion of amyloid accumulation in the seminal vesicle is unknown.

At least 25 different types of amyloidoses with different etiologies and related prognoses have been defined (1). Semenogelin I, has been defined as the amyloid protein that accumulates in VSA. Spectrometric analyses have revealed that this amyloid fibril consists of polypeptide fragments and these fragments are identical to the N-terminal region of the main secretion of the seminal vesicles (16).

The incidence of the hereditary disorder Familial Mediterranean Fever (FMF) and the related systemic AA amyloidosis is higher in our country than in others. AA amyloidosis is therefore frequently considered in amyloidosis cases. The aim of this study was to determine the amyloidosis frequency and evaluate its pathological characteristics in material obtained from radical prostatectomy performed for prostate adenocarcinoma.

\section{MATERIAL and METHODS}

A total of 207 consecutive cases operated on for prostate adenocarcinoma between December 2008 and December
2009 were evaluated in this study. The operation was performed at the Ege University Faculty of Medicine (EU) in 111 cases and the Dokuz Eylul University Faculty of Medicine (DEU) in 96 cases. Material obtained from radical cystoprostatectomy cases for bladder tumor was not included in this study. The prostatectomy material of the cases included in the study were processed according to the macroscopy standards of the uropathology working group.

Samples containing the seminal vesicles were routinely stained with Congo Red as well during the study. Puchtler's Alkaline Congo Red technique was used for Congo Red staining $(17,18)$. The slides were evaluated with light and polarized light microscopy and accumulations that stained with Congo Red and showed apple green reflection on the polarized light microscope were accepted as amyloid deposits. The subepithelial region, vessel walls and prostate parenchyma were also evaluated regarding amyloid accumulation. The clinical features of the cases have been collected from the pathology archive records.

\section{RESULTS}

Amyloid accumulation that stained bright red with Congo Red was found in 10 of the radical prostatecomy cases (mean value $4.8 \%$ in general, $3.6 \%$ for $\mathrm{EU}$ and $6.25 \%$ for DEU) (Figure 1-3). All cases had nodular, subepithelial deposits localized to the seminal vesicle (Figure 1,2) that gave an apple green reflection on polarized light microscopy (Figure 3). When no amyloid was observed in the vessel walls, prostate parenchyma or neighboring fibroadipose tissue, all cases were diagnosed as localized VSA.

The mean age of the VSA cases was $66.2 \pm 4.1$ years.

The Gleason grades of the prostate carcinoma cases was $6 / 10(3+3)$ in 62 cases, $7 / 10(3+4)$ in 100 cases, $7 / 10(4+3)$

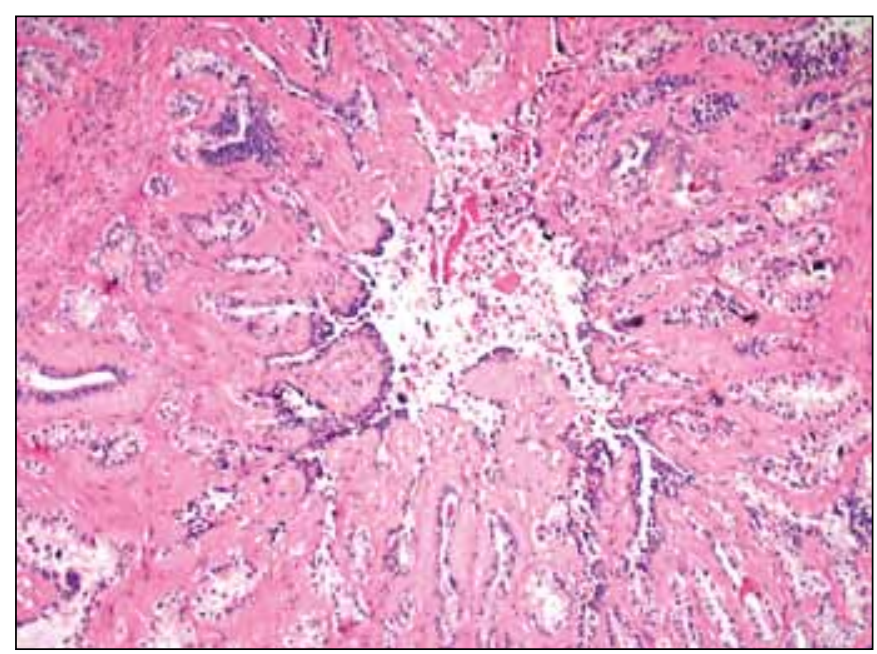

Figure 1: Apperance of nodular amyloid deposits with a subepithelial location in the seminal vesicle on light microscopy (H\&E, x40). 


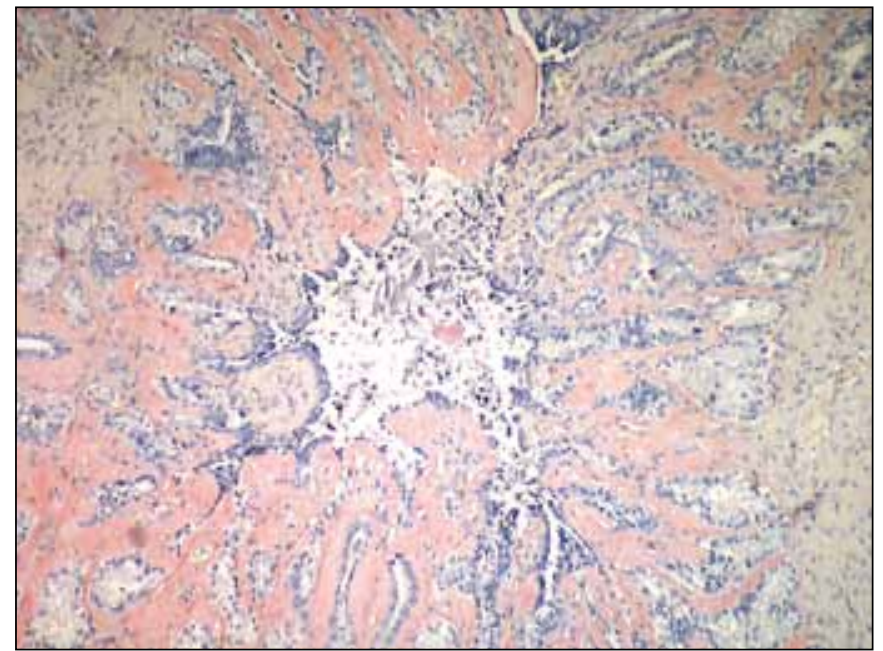

Figure 2: Amyloid deposits that are amorphous and pink-red with Congo Red in the seminal vesicle on light microscopy (Congo Red, x40).

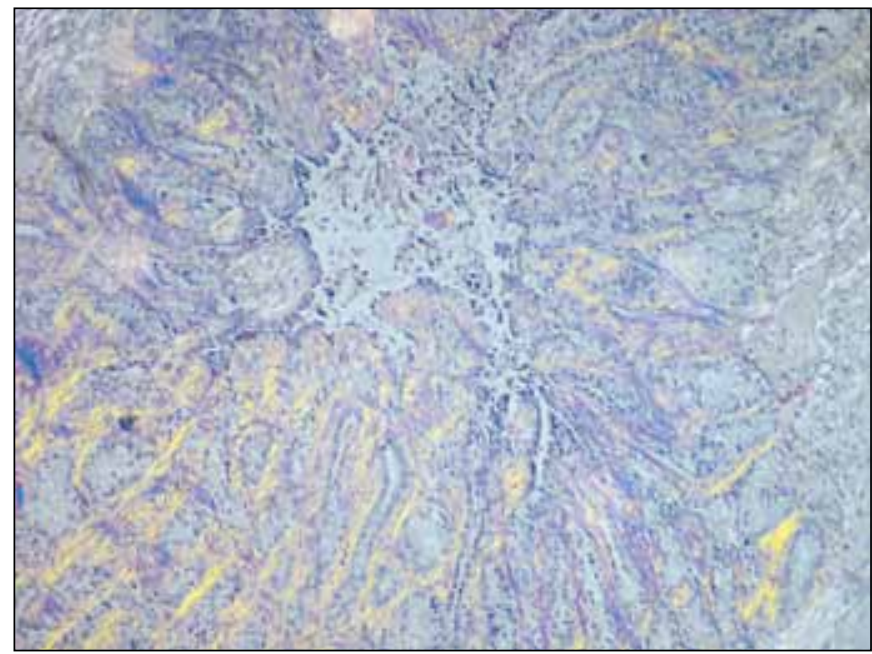

Figure 3: Appearance of amyloid deposits with apple green reflection on polarized light microscopy (Congo Red, polarized microscope, $\mathrm{x} 40$ ).

Table I: Distribution of the cases by Gleason Score

\begin{tabular}{|l|l|r|r|r|r|r|c|c|}
\hline \multicolumn{2}{|l|}{ Gleason score } & \multicolumn{1}{|c|}{$\mathbf{3 + 3}$} & $\mathbf{3 + 4}$ & $\mathbf{4 + 3}$ & $\mathbf{4 + 4}$ & $\mathbf{4 + 5}$ & $\mathbf{5 + 4}$ & Total number of cases \\
\hline VSA (-) cases & Number (\%) & $59(30)$ & $97(49)$ & $35(18)$ & $2(1)$ & $3(2)$ & $1(1)$ & $197(100)$ \\
\hline VSA (+) cases & Number (\%) & $3(30)$ & $3(30)$ & $4(40)$ & - & - & - & $10(100)$ \\
\hline
\end{tabular}

Explanation; VSA (-) cases: Cases where seminal vesicle amyloidosis was not observed; VSA (+) cases: Cases with seminal vesicle amyloidosis.

in 39 cases, 8/10 (4+4) in 2 cases, 9/10 (4+5) in 3 cases and $9 / 10(5+4)$ in 1 case. Table I presents the distribution of cases with and without VSA. A tertiary pattern was present in 41 cases. The pathological stage was $2 \mathrm{a}$ in 22 cases, $2 \mathrm{~b}$ in 8 cases, $2 \mathrm{c}$ in 113 cases, $3 \mathrm{a}$ in 48 cases and $3 \mathrm{~b}$ in 16 cases. The pathological stage was $2 \mathrm{c}$ in $7,2 \mathrm{~b}$ in 2 and $3 \mathrm{a}$ in 1 of the 10 cases where amyloid deposits were found. Seminal vesicle invasion and/or metastasis was not found in any case with amyloid deposits.

\section{DISCUSSION}

FMF-related systemic AA amyloidoses are common in the Mediterranean region where our country is also located and data related to hereditary cases or VSA have not been defined. We investigated VSA in 207 consecutive cases from two large centers in this study and found a deposit rate of $4.8 \%$. These deposits were localized and the data obtained from these evaluations are the first for the frequency of seminal vesicle amyloidosis in our country.

The amyloid that collects in the tissues is amorphous pink on hematoxylin eosin staining while Congo Red staining and polarized light microscopy evaluation differentiates them from other proteinaceous deposits by the apple green birefringence. Amyloid deposits are fibrillar and consist of 8-12 nm fibrils with 8-folded layering on electron microscopy. Amyloidoses can be systemic or localized. Localized amyloid deposits can be as small as a single focus on microscopy or as large as to create a nodular mass. Localized amyloidosis has been defined in many organs (19-24). Localized amyloidoses are thought to be amyloid deposits derived from the proteins synthesized at the cells located in the region of accumulation (1). Localized amyloidosis can be seen together with neuroendocrin tumors (Acal, related to calcitonin) in surgical material. The amyloid protein that accumulated in localized VSA is named "Semenogelin I" (ASem). Linke et al. have demonstrated that Semenogelin I consists of polypeptide fragments and these fragments are identical to the $\mathrm{N}$-terminal region of the main secretion produced by the seminal vesicle (16). It is suggested that localized amyloidosis histogenesis is via the accumulation of the exocrine secretory product of the lining epithelium of the ejaculatory ductus system in the subepithelial seminal vesicle, vas deference and ejaculatory ducti by local diffusion $(7,16)$.

On histopathologic evaluation, the subepithelial location of the seminal vesicle deposits without observing any in the parenchyme or vessel walls is the most important feature differentiating VSA from the systemic amyloidoses. We observed these same findings as in previous studies and they guided us in the VSA diagnosis. 
The incidence of VSA in prostatectomy material performed for prostate adenocarcinoma in this study was lower than in the autopsy series in the literature but was consistent with the $4.7 \%$ rate reported by Kee et al. for prostatectomy material (7). Kee et al. have found a difference between two institutions that took care of American and Korean patients as in this study (7). Although the incidence is similar in the two studies, having multicenter studies with a larger number of cases when we take the between-institution incidence variability into account would enable reaching a more balanced decision,

In contrast to the Pitkanen et al. study, the mean age of the cases with localized amyloidosis was quite similar to that of other cases (6). We found no relationship between age and the accompanying prostate adenocarcinoma pathological stage with the amyloid accumulation factors such the Gleason score and grade of the tumor and patient age are also effective in the clinical selection criteria of prostate cancer patients at present and we therefore did not undertake statistical analysis.

There are only a limited number of studies on the effect of localized amyloid deposits in the seminal vesicle on the invasion of prostate adenocarcinoma to this region. None of the patients with amyloid deposits in our study had seminal vesicle invasion. It may also be important to evaluate the relationship between the tumor and amyloid deposition as with other amyloidoses. Examples of other amyloidoses are the concurrence of AA amyloidosis and renal tumor, AL amyloidosis and plasma cell tumor for systemic forms and ACal amyloidosis and neuroendocrine carcinoma for localized forms. There are also some cases that have reported a malignancy with the defined ALect2 amyloidosis (25)

The differentiation of localized amyloidoses from systemic amyloidoses is quite important due to the different treatment. The first thing that comes to mind for amyloidosis is systemic AA amyloidosis in our country due to the frequency of FMF (26). We did not consider systemic amyloidosis in our cases in light of the literature data as there were no vascular amyloid deposits. We did not use commercial immunohistochemical markers against Semenogelin I for typing amyloid as they increase the cost despite the low number of cases. The VSA lesions were positive for lactoferrin and amyloid B protein. No positive reaction was found with antibodies against amyloid $\mathrm{A}$, kappa and lambda and Beta 2 microglobulin (11).

We found localized VSA that was consistent with series in cases operated on for prostate adenocarcinoma. This finding can create a suspicion of invasion on MR imaging and needs to be differentiated from systemic amyloidoses that require different treatment protocols and should therefore always be kept in mind by uropathologists. The association of this entity, not commonly seen in prostatectomy material, with tumors should be investigated in wider series.

\section{REFERENCES}

1. Westermark P, Benson MD, Buxbaum JN, Cohen AS, Frangione B, Ikeda S, Masters CL, Merlini G, Saraiva MJ, Sipe JD: A primer of amyloid nomenclature. Amyloid 2007, 14:179-183

2. Reynard JM, Shearer RJ: Localised amyloidosis of the urinary bladder. Br J Urology 1993, 72:656

3. Auge BK, Haluszka MM: Primary amyloidosis of the bladder. J Urology 2000, 163: 1867-1868

4. Kato H, Toei H, Furuse M, Suzuki K, Hironaka M, Saito K: Primary localized amyloidosis of the urinary bladder. Eur Radiol 2003, 13: L109-L112

5. Coyne JD, Kealy WF: Seminal vesicle amyloidosis: morphological, histochemical and immunohistochemical observations. Histopathology 1993, 22:173-176

6. Pitkanen P, Westermark P, Cornwell III GG, Murdoch W: Amyloid of the seminal vesicles. A distinctive and common localized form of senile amyloidozis. Am J Pathol 1983, 110: 64-69

7. Kee KH, Lee MJ, Shen SS, Suh JH, Lee OJ, Cho HY, Ayala AG, Ro JY: Amyloidosis of seminal vesicles and ejaculatory ducts: a histologic analysis of 21 cases among 447 prostatectomy specimens. Ann Diagn Pathol 2008, 12: 235-238

8. Seidman JD, Shmookler BM, Connolly B, Lack EE: Localized amyloidosis of seminal vesicles: report of three cases in surgically obtained material. Mod Pathol 1989, 2: 671-675

9. Jun SY, Kim KR, Cho KS, Ro JY: Localized amyloidosis of seminal vesicle and vas deferens: report of two cases. J Korean Med Sci 2003, 18: 447-451

10. Harvey I, Tetu B: Amyloidosis of seminal vesicles: a local condition with no systemic impact. Ann Pathol 2004, 24: 236-240

11. Furuya S, Masumori $N$, Furuya $R$, Tsukamoto T, Isomura H, Tamakawa M: Characterization of localized seminal vesicle amyloidosis causing hematospermia: an analysis using immunohistochemistry and magnetic resonance imaging. J Urol 2005, 173: 1273-1277

12. Schaeffer EM, Epstein JI, Walsh PC: Amyloidosis of the seminal vesicles and hematospermia. J Urol 2004, 171:2382

13. Maroun L, Jakobsen H, Kromann-Andersen B, Horn $T$ : Amyloidosis of the seminal vesicle - a case report and review of the literature. Scand J Urol Nephrol 2003, 37: 519-521

14. Jager GJ, Ruijter ET, de la Rosette JJ, van de Kaa CA: Amyloidosis of the seminal vesicles simulating tumor invasion prostatic carsinoma on endorectal MR images. Eur Radiol 1997, 7: 552-554

15. Ramchandani P, Schnall MD, Livolsi VA, Tomaszewski JE, Pollack HM: Senile amyloidosis of seminal vesicles mimicking metastatic spread of prostatic carcinoma on MR images. AJR Am J Roentgenol 1993, 161: 184-185 
16. Linke RP, Joswig R, Murphy CL, Wang S, Zhou H, Gross U, Rocken C, Westermark P, Weiss DT, Solomon A: Senile seminal vesicle amyloid is derived from semenogelin I. J Lab Clin Med 2005, 145: 187-193

17. Westermark GT, Johnson KH, Westermark P: Staining methods for identification of amyloid in tissue. Methods Enzymol 1999, 309: 3-25

18. Puchtler H, Sweat F, Levine M: On the binding of Congo red by amyloid. J Histochem Cytochem 1962, 10:355-364

19. Biewend ML, Menke DM, Calamia KT: The spectrum of localized amyloidosis: a case series of patients and review of the literature. Amyloid 2006, 13:135-142

20. Paccalin M, Hachulla E, Cazalet C, Tricot L, Carreiro M, Rubi M, Grateau G, Roblot P: Localized amyloidosis: a survey of 35 French cases. Amyloid 2005, 12:239-245

21. Siddachari RC, Chaukar DA, Pramesh CS, Naresh KN, de Souza CE, Dcruz AK: Laryngeal amyloidosis. J Otolaryngol 2005, 34: 60-63
22. Benneth JD, Chowdhury CR: Primary amyloidosis larynx. J Laryngol Otol 1994, 108: 339-340

23. Rubinow A, Celli BR, Cohen AS, Rigden BG: Localized amyloidosis of the lower respiratory tract. Respir Dis 1978, 118: 603-611

24. Fugita OE, DeLatorre CG, Kavoussi LR: Primary amyloidosis of the ureter. Urology 2001, 58: 281

25. Larsen CP, Walker PD, Weiss DT, Solomon A: Prevalence and morphology of leukocyte chemotactic factor 2-associated amyloid in renal biopsies. Kidney Int 2010, 77: 816-819

26. Şen S, Sarsık B: A proposed histopathologic classification, scoring, and grading system for renal amyloidosis: standardization of renal amyloid biopsy report. Arch Pathol Lab Med 2010, 134: $532-544$ 